\title{
Hubungan Kadar Limfosit Total dengan Prognosis Penyakit pada Penderita Sirosis Hati di Bagian Penyakit Dalam RSUP Dr. M. Djamil Padang Tahun 2011
}

\author{
Vyola Regina, Arnelis, Zulkarnain Edward
}

\begin{abstract}
Abstrak
Sirosis hati adalah stadium akhir dari penyakit hati kronik berupa proses fibrosis difus yang ditandai dengan perubahan arsitektur normal hati menjadi bentuk nodulus abnormal. Pada penderita sirosis hati ini sering terjadi penyakit infeksi akibat adanya imunosupresi. Hitung kadar limfosit total dapat digunakan untuk menentukan status imunitas penderita sirosis hati. Tujuan penelitian ini adalah mengetahui kadar limfosit total penderita sirosis hati. Jenis penelitian ini adalah deskriptif analitik. Populasi penelitian adalah penderita sebagai sirosis hati yang dirawat di Bagian Penyakit Dalam RSUP Dr. M. Djamil Padang pada tahun 2011. Sampel diambil dari populasi yang memenuhi kriteria inklusi dan eksklusi. Data diolah menggunakan uji Chi-square. Dari hasil penelitian didapatkan bahwa sebanyak $83,1 \%$ penderita sirosis hati memiliki kadar limfosit total yang rendah. Terdapat hubungan kadar limfosit total dengan berat ringannya penyakit sirosis hati dengan $\mathrm{p}<0,05$. Sebanyak $49,2 \%$ infeksi ditemukan pada penderita sirosis hati. Kematian pada penderita sirosis hati akibat penyakit infeksi ditemukan 52,9\%.
\end{abstract}

Kata kunci: kadar limfosit total, sirosis hati

\begin{abstract}
Liver Cirrhosis is the end stage of chronic liver disease in the form of a diffuse fibrotic process characterized by changes in the normal architecture of the liver to abnormal nodules. In patients with liver cirrhosis is common infections due to immunosuppression. The total lymphocyte count can be used to determine the immune status of patients with liver cirrhosis. The purpose of this study was to determine total lymphocyte count of liver cirrhosis patients. This research design is descriptive analytic. The population is the liver cirrhosis patients as treated in the Internal Medicine Dr. M. Djamil Padang in 2011. Samples were taken from the population that meet the inclusion and exclusion criteria. The data processed by Chi-square test.The results of this study indicated that as many as $83,1 \%$ of cirrhosis patients have a low total lymphocyte count. There is a relationship of total lymphocyte levels with severity of liver cirrhosis with a value of $p<0,05$. The infections found $49.2 \%$ of cirrhosis patients. Mortality in cirrhosis patients due to infection was found $52,9 \%$
\end{abstract}

Keywords:total lymphocyte count, liver cirrhosi

Affiliasi penulis : Vyola Regina,

Korespondensi : Fakultas Kedokteran Universitas Andalas, email : regina.vyolet@gmail.com, Telp/Hp: 083181760065

\section{PENDAHULUAN}

Sirosis hati merupakan penyakit hati yang sering ditemukan di Indonesia. Di RS Dr. Sardjito Yogyakarta tahun 2004 jumlah pasien sirosis hati yang dirawat di Bagian Penyakit Dalam sekitar 4,1\%, sedangkan di Medan ditemukan sebanyak 819 (4\%) dalam waktu 4 tahun. ${ }^{1}$ Hasil penelitian tahun 2001 di Bangsal Penyakit Dalam RSUP Dr. M. Djamil Padang, penderita sirosis hati dijumpai 388 (64,99\%) dari 597 penderita penyakit hati. $^{2}$

Pada penderita sirosis hati terjadi hipertensi portal yang menyebabkan splenomegali sekitar 36 92\%. ${ }^{3}$ Splenomegali mengakibatkan hiperslenismus yaitu peningkatan kerja limpa dalam penghancuran komponen darah termasuk leukosit. Keadaan leukopenia akan menimbulkan kelainan sistem imun berat pada penderita sirosis hati. Imunosupresi akan mengakibatkan tingginya penyakit infeksi pada penderita sirosis hati. ${ }^{4}$ Komplikasi infeksi yang sering terjadi antara lain SBP (Spontaneous Bacterial Peritonitis), Infeksi Traktus Urinarius, Infeksi Saluran Pernapasan dan Bakteriemia. ${ }^{5}$ Bahkan penderita sirosis hati memiliki resiko kematian karena sepsis lebih tinggi dibandingkan dengan penderita nonsirosis akibat imunosupresi.
Hitung kadar limfosit total yang merupakan salah satu parameter untuk menetukan status imunitas seseorang dapat dilakukan pada penderita sirosis hati. Tingginya angka sirosis hati dan angka infeksi pada penderita sirosis hati menjadi dasar penulis untuk meninjau kadar limfosit total penderita sirosis hati di RSUP Dr. M. Djamil Padang.

\section{Masalah}

Berdasarkan uraian latar belakang di atas didapatkan rumusan masalah sebagai berikut :

1. Bagaimana kadar limfosit total berdasarkan berat ringannya penyakit sirosis hati ?

2. Berapa besar angka infeksi pada penderita sirosis hati berdasarkan kadar limfosit total ?.

3. Berapa besar dampak penurunan kadar limfosit total terhadap mortalitas penderita sirosis hati ?

Tujuan Penelitian

1. Tujuan Umum

Mengetahui hubungan kadar limfosit total dengan prognosis penderita sirosis hati di Bagian Penyakit Dalam RSUP Dr. M. Djamil Padang.

2. Tujuan Khusus

a. Untuk mengetahui kadar limfosit total berdasarkan berat ringannya penyakit (klasifikasi Child) sirosis hati. 
b. Untuk mengetahui angka infeksi pada penderita sirosis hati berdasarkan kadar limfosit total.

c. Untuk mengetahui berapa banyak kasus infeksi sebagai penyebab kematian pada penderita sirosis hati.

\section{Manfaat Penelitian}

Dengan mengetahui kadar limfosit total penderita sirosis hati serta penyakit infeksi yang timbul kita dapat :

1. Meramalkan prognosa penyakit sirosis hati.

2. Melakukan intervensi lebih ketat terhadap kemungkinan terjadinya infeksi serta pemberian antibiotik profilaksis pada penderita sirosis hat dengan status imunitas rendah.

\section{METODE}

Jenis penelitian ini adalah deskriptif analitik. Penelitian retrospektif ini populasinya adalah pasien Sirosis hati yang dirawat di Bagian Penyakit Dalam RSUP Dr. M. Djamil Padang tahun 2011 yang diambil dari data rekam medik. Sementara sampelnya adalah data yang memenuhi kriteria inklusi dan eksklusi. Penelitian dilakukan dari bulan Juni sampai November 2012. Pengambilan data meliputi data dasar pasien (umur, jenis kelamin), hasil pemeriksaan fisik dan laboratorium (terutama jumlah leukosit, hitung jenis leukosit, kadar bilirubin, albumin dll). Hasil pemeriksaan laboratorium yang dilihat adalah saat pasien pertama dirawat di rumah sakit. Analisis data menggunakan uji Chi-square dengan derajat kepercayaan $95 \%(\alpha=0,05)$. Untuk melihat nilai kemaknaan perhitungan statistik digunakan batas kemaknaan 0,05 . $^{7}$

\section{HASIL PENELITIAN}

Dari 183 penderita Sirosis hati tahun 2011 hanya 65 (36\%) yang dapat dijadikan sampel. Berikut adalah karakteristik sampel penelitian :

Tabel 1. Karakteristik sampel Sirosis hati

\begin{tabular}{|c|c|c|}
\hline Variabel & $\begin{array}{c}\text { Jumlah } \\
\text { Penderita } \\
\text { Sirosis Hati }\end{array}$ & $\%$ \\
\hline $\begin{array}{l}\text { Umur } \\
37-43 \\
44-50 \\
51-57 \\
58-64 \\
65-71\end{array}$ & $\begin{array}{c}14 \\
23 \\
14 \\
10 \\
4\end{array}$ & $\begin{array}{c}21,5 \\
35,4 \\
21,5 \\
15,4 \\
6,2\end{array}$ \\
\hline $\begin{array}{l}\text { Jenis } \\
\text { kelamin } \\
\text { Laki- laki } \\
\text { Wanita }\end{array}$ & $\begin{array}{l}37 \\
28\end{array}$ & $\begin{array}{l}56,9 \\
43,1\end{array}$ \\
\hline $\begin{array}{l}\text { Klaifikasi } \\
\text { Child } \\
\text { Child A } \\
\text { Child B } \\
\text { Child C }\end{array}$ & $\begin{array}{l}10 \\
33 \\
22\end{array}$ & $\begin{array}{l}15,38 \\
50,77 \\
33,85\end{array}$ \\
\hline $\begin{array}{l}\text { Kadar } \\
\text { Limfosit } \\
\text { Total } \\
\text { Normal } \\
\text { Rendah }\end{array}$ & $\begin{array}{l}11 \\
54\end{array}$ & $\begin{array}{l}16,9 \\
83,1\end{array}$ \\
\hline
\end{tabular}

Dari tabel di atas dapat dilihat bahwa penderita sirosis hati terbanyak pada kelompok umur $44-50$ yaitu sebesar $35,4 \% \quad(S D=1,174)$ sedangkan jumlah penderita terkecil adalah pada kelompok umur 65 - 71 sebesar 6,2\%. Mean dari data umur penderita sirosis hati di atas adalah 50,26 dengan range 31 .

Bila ditinjau dari jenis kelamin, penderita sirosis hati yang berjenis kelamin laki-laki lebih banyak ditemukan yaitu 37 kasus $(56,9 \%)$ sedangkan yang wanita 28 kasus $(43,1 \%)$ dengan perbandingan lakilaki : wanita $=1,3: 1$.

Tabel di atas juga menunjukkan derajat penyakit sirosis hati pada pasien yang dirawat di Bagian Penyakit Dalam RSUP Dr. M. Djamil Padang. Dari 65 sampel penelitian, yang terbanyak dirawat adalah penderita sirosis hati dengan derajat penyakit Child B yaitu 50,77\%. Sementara untuk Child A didapatkan $15,38 \%$ dan Child C sebanyak 33,85\%.

Berdasarkan kadar limfosit total, penderita sirosis hati yang dirawat dengan limfosit total normal ditemukan sebanyak 11 kasus (16,9\%) sedangkan yang mengalami penurunan limfosit total sebanyak 54 kasus $(83,1 \%)$.

Tabel 2. Kadar limfosit total berdasarkan berat ringan Sirosis hati

\begin{tabular}{lcccccc}
\hline Variabel & \multicolumn{3}{c}{ Kadar limfosit total } & \multicolumn{2}{c}{ Total } \\
\cline { 1 - 6 } Klasifikas & \multicolumn{2}{c}{ Normal } & \multicolumn{2}{c}{ Rendah } & & \\
\cline { 2 - 6 } i Child & $\mathbf{f}$ & $\%$ & $\mathbf{f}$ & $\%$ & $\mathbf{f}$ & $\%$ \\
\hline Child A & 2 & 3,1 & 8 & 12,3 & 10 & 15,38 \\
Child B & 8 & 12,3 & 25 & 38,5 & 33 & 50,77 \\
Child C & 1 & 1,5 & 21 & 32,3 & 22 & 33,85 \\
\hline Total & 11 & 16,9 & 54 & 83,1 & 65 & 100 \\
\hline \multicolumn{7}{c}{$\quad \mathrm{p}=0,043$}
\end{tabular}

Dari tabel 2 terlihat bahwa setiap derajat penyakit sirosis hati (klasifikasi Child) mengalami penurunan jumlah limfosit total walaupun masih terdapat kadar limfosit total yang normal. Terdapatnya hubungan antara berat ringanya penyakit sirosis hati dengan kadar limfosit total dengan $p<0,05$.

Tabel 3. Distribusi frekuensi penderita Sirosis hati yang mengalami infeksi

\begin{tabular}{lcc}
\hline Sirosis Hati & Frekuensi & $\%$ \\
\hline Infeksi & 32 & 49,2 \\
Tidak infeksi & 33 & 50,8 \\
\hline Total & 65 & 100 \\
\hline
\end{tabular}

Angka infeksi cukup tinggi ditemukan pada penderita Sirosis hati yaitu $49,2 \%$. Bila ditinjau dari kadar limfosit total, maka penderita dengan kadar limfosit total rendah angka infeksinya lebih tinggi dibandingkan penderita dengan kadar limfosit total normal. Dari 32 total infeksi, sebanyak 26 kasus $(81,3 \%)$ infeksi terjadi pada penderita dengan kadar limfosit total rendah, sedangkan pada kadar limfosit total yang normal ditemukan $18,7 \%$ saja.

Didapatkan 17 kematian pada penderita sirosis hati, $9(52,9 \%)$ diantaranya disebabkan oleh penyakit infeksi dan sisanya $47,1 \%$ disebabkan oleh pecahnya varises esofagus, koma hepatikum, dll. Ditinjau dari kadar limfosit total, kematian penderita Sirosis hati karena infeksi adalah sebagai berikut: 
Tabel 4. Kematian pada penderita Sirosis hati yang terinfeksi berdasarkan kadar limfosit total

\begin{tabular}{|c|c|c|c|c|c|c|}
\hline \multirow{3}{*}{$\begin{array}{c}\text { Kematian pada } \\
\text { Sirosis Hati }\end{array}$} & \multicolumn{4}{|c|}{ Kadar Limfosit Total } & \multirow{3}{*}{$\begin{array}{c}\text { Tot } \\
\text { al }\end{array}$} & \multirow[t]{3}{*}{$\%$} \\
\hline & \multicolumn{2}{|c|}{ Normal } & \multicolumn{2}{|c|}{ Rendah } & & \\
\hline & $f$ & $\%$ & $f$ & $\%$ & & \\
\hline $\begin{array}{c}\text { Non Infeksi } \\
\text { Infeksi }\end{array}$ & $\begin{array}{l}3 \\
1\end{array}$ & $\begin{array}{c}17,6 \\
5,9\end{array}$ & $\begin{array}{l}5 \\
8\end{array}$ & $\begin{array}{l}29,4 \\
47,1\end{array}$ & $\begin{array}{l}8 \\
9\end{array}$ & $\begin{array}{l}47,1 \\
52,9\end{array}$ \\
\hline Total & 4 & 23,5 & 13 & 76,5 & 17 & 100 \\
\hline
\end{tabular}

Kematian karena infeksi pada penderita sirosis hati dengan limfosit total normal sebesar 5,9\% sedangkan pada kadar limfosit total rendah didapatkan sebanyak $52,9 \%$.

\section{PEMBAHASAN}

Penderita yang memenuhi kriteria sampe adalah 65 kasus, hal ini disebabkan oleh keterbatasan data yang diperoleh dari rekam medik pasien. Berdasarkan klasifikasi Child didapatkan penderita dengan Child A sebanyak $15,38 \%$ dan Child B $50,77 \%$. Jumlah ini sedikit lebih rendah dari hasil penelitian Ilhami (2) yang mendapatkan Child A sebanyak $15,77 \%$ dan Child B $61,44 \%$. Namun untuk Child C didapatkan sebanyak $33,85 \%$, angka ini lebih besar dibandingkan penelitian terdahulu yaitu $22,69 \%$.

Dari 65 penderita hanya $11(16,9 \%)$ yang memiliki kadar limfosit total normal sedangkan 83,1\%nya mengalami penurunan. Ditemukan sebanyak 32 kasus $(49,2 \%)$ infeksi pada penderita sirosis hati. Pada penderita dengan kadar limfosit total rendah didapatkan angka infeksi 81,3\%. Angka ini lebih tinggi dibandingkan penelitian Tandon et a $\hat{f}$ yang mendapatkan angka infeksi pada penderita sirosis hat sebesar $34 \%$. Hal ini juga sesuai dengan yang dikemukakan A.M Atallah et $a^{\beta}$ bahwa munculnya penyakit infeksi pada penderita sirosis hati akibat gangguan imunitas.

Angka kematian pada penderita sirosis hati adalah $26,2 \%$ yang lebih rendah dibandingkan hasil penelitian Ilhami ${ }^{2}$ yang mendapatkan angka kematian sebesar $31,35 \%$. Hal ini mungkin disebabkan oleh beberapa penderita keluar dari Rumah Sakit (pulang paksa) sehingga tidak diketahui kematiannya. Dari 32 kasus sirosis hati yang telah mengalami infeksi, kematian terjadi sebesar $28,1 \%$. Bila ditinjau dari 17 kasus yang mengalami kematian di Rumah Sakit, yang diakibatkan oleh penyakit infeksi ditemukan sebesar $52,9 \%$. Sedikit berbeda dengan Fernandez yang mendapatkan kematian pada penderita sirosis hati akibat infeksi sebesar $30 \%$.

Bila ditinjau dari kadar limfosit total, penderita dengan kadar limfosit total rendah memiliki angka kematian akibat infeksi lebih besar yaitu 47,1\% dibandingkan penderita dengan kadar limfosit total normal $(5,9 \%)$. Dari analisis statistik yang dilakukan antara kadar limfosit total dengan kematian karena infeksi pada penderita sirosis hati didapatkan nilai $p=0,030$ yang kecil dari nilai a sehingga dapat disimpulkan bahwa terdapat hubungan yang bermakna antara kadar limfosit total dengan kematian karena infeksi pada penderita sirosis hati.
Hal ini sesuai dengan Tandon et af yang mengungkapkan bahwa penderita sirosis hati memiliki resiko kematian karena sepsis lebih tinggi akibat imunosupresi.

\section{Daftar Pustaka}

1. Siti N, 2009. Sirosis hati. Buku ajar ilmu penyakit dalam. Ed 5, Jakarta: Internal Publishing, 668-73.

2. Ilhami $F, 2001$. Gambaran sirosis hepatis di bagian penyakit dalam RSUP Dr. M. Djamil Padang periode januari 1999 sampai desember 2000. Skripsi. Fakultas Kedokteran Unand.

3. McCormick PA, 2007. Hyperslenism. Textbook of hepatology. Ed 3, USA: Blackwell Publishing, 784-90.

4. Marquez M, C.F Gutierrez, M.M de Oca, M.J. Blanco, F. Brun, C.R Ramos, et al, 2009. Chronic antigenic stimuli as a possible explaination for the immunodepression caused by liver cirrhosis. Clinical and experimental immunology. British Society for Immunology, 158: 219-29.

5. Fernandez J, Miguel N, 2007. Bacterial infection in portal hypertension. Textbook of hepatology. Ed 3, USA: Blackwell Publishing, 761-70.

6. Tandon P, G. Garcia-Tsao, 2008. Bacterial infections, sepsis and multiorgan failure in cirrhosis. Seminars in liver disease. New York: Thieme Medical Publishers.

7. Budiarto E, 2002. Biostatistika untuk kedokteran dan kesehatan masyarakat. Jakarta: EGC.

8. Attallah AM, AA. Tabll, M. El-Sadany, T.A Ibrahim, I. El-Dosoky, 2003. Dysregulation of blood lymphocyte subsets and natural killer cells in liver disease and hepatocellular carcinoma. Clin Exp Med, 3: 181-5. 